\title{
Erratum to: Investigation of organic pollutants in wastewater-irrigated soil and its DNA damage and oxidative damage on mice
}

\section{Hongxia Gao • Yidian Dong • Chunyan Meng • Weijun Guan • Yingli Liu • Guizhi Xing}

Published online: 19 September 2012

(C) Springer Science+Business Media B.V. 2012

\section{Erratum to: Environ Monit Assess DOI 10.1007/s10661-012-2725-7}

In the original publication of this article, Figs. 2, 3 and 4 were displayed without the asterisk keys and number signs indicating the $\mathrm{p}$ values. The correct figures are presented here.

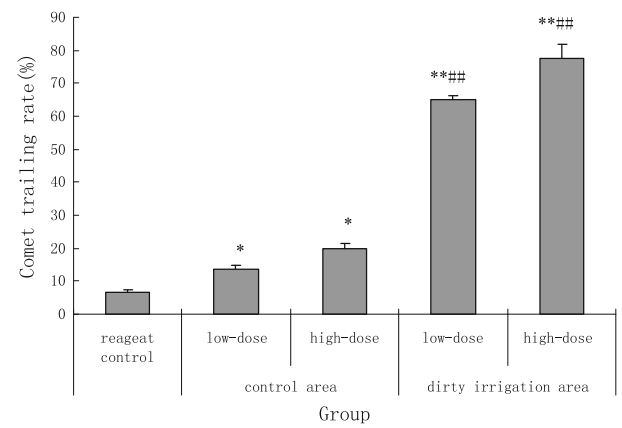

Fig. 2 The level of DNA damage in peripheral blood lymphocytes of mice for tailing rate in the comet assay. The results are expressed as mean $\pm \mathrm{SD}$. $\mathrm{n}=8 /$ per group. Compared with reagent control group $* \mathrm{p}<0.05, * * \mathrm{p}<0.01$. Compared with control group of same dose $\# \mathrm{p}<0.05, \# \# \mathrm{p}<0.01$

The online version of the original article can be found at http://dx.doi.org/10.1007/s10661-012-2725-7.

H. Gao $(\bowtie) \cdot$ C. Meng $\cdot$ W. Guan $\cdot$ Y. Liu $\cdot$ G. Xing

School of Public Health, Hebei United University,

Tangshan, Hebei, China

e-mail: ghxgao@126.com

Y. Dong

Civil and Environmental Engineering Department, Imperial

College London,

London, UK

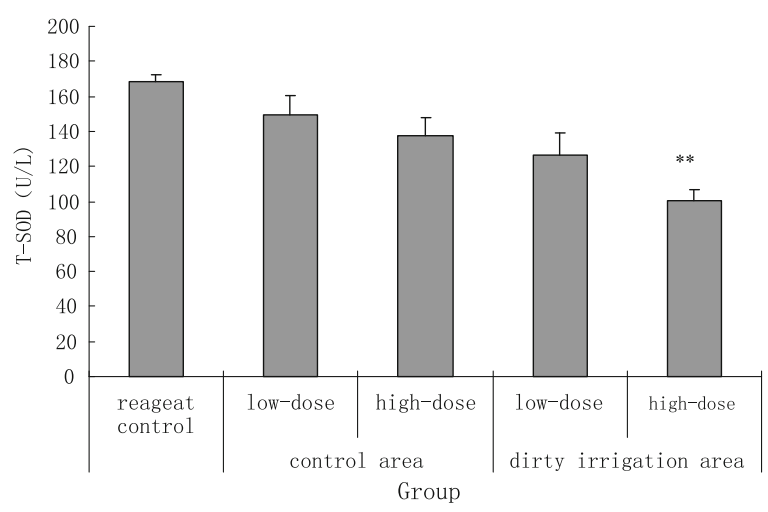

Fig. 3 The activity of TSOD in serum of mice exposed to different sampling area of organic extracts in soil. The results are expressed as mean $\pm \mathrm{SD} . \mathrm{n}=8$ animals/treatment. Compared with reagent control group $* * \mathrm{p}<0.01$

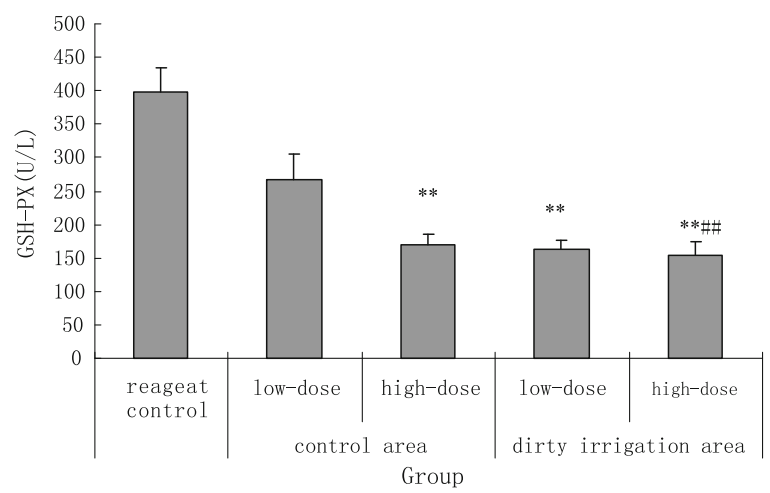

Fig. 4 The activity of TSOD in serum of mice exposed to different sampling area of organic extracts in soil. The results are expressed as mean \pm SD. $n=8$ animals/treatment. Compared with reagent control group $* * \mathrm{p}<0.01$. Compared with control group of same dose $\# \mathrm{p}<0.05, \# \# \mathrm{p}<0.01$ 